\title{
Psycho-Historical Perceptions of Gandhi
}

\author{
Vijayalakshmi K $S^{*}$
}

\section{Abstract}

The literature on leadership has its roots in the "Great Man" Theory of Thomas Carlyle, who declared that "The history of the world is but the biography of great men". These works which emphasised only political, economic, and social motivations for events, gave way to Erikson's, "Gandhi's Truth: On the Origins of Militant Nonviolence", is an attempt at understanding Gandhi through a Psycho-biographical study. Psycho-history analyses the incidents that left a deep impression on Gandhi and examines these experiences that Gandhi used on his techniques such as fasting, Ahimsa and Satyagraha later on. The present paper is a historiographical account of the psycho-historical writings on Gandhi. Erikson's seminal work which actually gained for Psychohistory its recognition, forms the major source of this paper and also includes some more recently published works such as Wolpert, Richards and Lelyveld. These narratives have explored the varied facets of his personality and his identity which had blurred between myth and history. Gandhi in most writings is raised to the stature of the Mahatma, but psycho-history has done justice to his character as it brings out the human side of the leader with all his frailties.

Keywords: Mahatma Gandhi, Psychohistory, Historiography

\section{Introduction}

History is witness to the rise of several leaders who have navigated through difficult times. One ponders on the circumstances that

*Bangalore University, Bengaluru, India; vijukori@gmail.com 
evoked leadership qualities in such people. Some rise to become leaders against adverse conditions, while others achieve it without any efforts. Whatever be their circumstances, it has become commonplace to see such leaders being conferred the honorific of a "Great Leader". Were these born leaders? Do they deserve to be called great? These are some of the common questions that concern the writers of the history of leadership.

Leadership literature is replete with narratives in the form of biographies in the traditional historical analysis, and additionally with only a few honouring accuracy. Biographical works are like a journey into the past, attempting to depict the personality, and the life and times of a leader, with a view to understanding the events that molded the leader. The literature on leadership has its roots in "Great Man" Theory associated with the nineteenth-century Scottish historian Thomas Carlyle, who declared that "The history of the world is but the biography of great men" (Carlyle, 1899). Additionally, biographical writings mostly tend to turn into hagiographies.

The "Great Man" theory eventually gave way to new forms of writing biographies which recognised that circumstances alone do not shape these leaders. Psychological motivations also make them behave in the manner they did which drove them to such heights of leadership.

Traditional historical explanations emphasised the political, economic, social and cultural and intellectual motivations for events and actions, without really explaining why humans behave in the manner they did. Most often these accounts do not take into consideration the psychological motivations. Psychohistory attempts to fill this gap.

Psychiatrists and psychologists go to the extremes by claiming that some of the greatest leaders in history have had mental health problems and it may have helped them in times of crisis. Katherine Nordal, a Psychologist, avers that some of these mental problems, in fact, make for their greatness (De Graf, 2016).

Gandhi has been a subject of fascination for many a student of history; he has held centre-stage in history books for a long time. There are many biographies of Gandhi that have been written, 
apart from Gandhi's autobiography. Most of these works are traditional narratives. One of the first works on Gandhi that deviated from this was Philip Spratt's, "Gandhism: An Analysis", published in 1939, a psychoanalytical work that took into account the mental development of Gandhi from his childhood days which was instrumental in his actions of later days1. The present paper is a historiographical account of the psycho-historical writings on Gandhi. Erikson's seminal work which actually gained recognition for Psychohistory, forms the major source of this paper and it also includes some more recently published works such as Wolpert, Richards and Lelyveld. These narratives have explored the varied facets of Gandhi's personality and identity which had been blurred between myth and history.

Psycho-history is a relatively new field, and is interdisciplinary, as the name indicates. It has grown in methodological sophistication and popular acceptance since the late 1950's. Psychohistory is simply defined as the psychological analysis of history. This involves the interpretation of people and events according to the present knowledge and perspectives regarding human emotions, thought and behaviour (Piven, 2001).

Psycho-historians add a neglected but critically important level of explanation - identification of the unconscious motivations of individuals and groups. Three areas of interrelated Psychohistorical research are - History of childhood, Psychobiography, and Group Psychology

Psychobiography seeks to understand individual historical actors and their motivations. It involves reconstruction of a person's emotional development; family and social relationships; decisions and actions; the interaction of all these factors within the cultural and political context of the person's time and place2. The historian's prospect of learning this new method promises to illuminate old areas of traditional historical interest (Mazlish, 1971).

It was only after the Second World War that Psychohistory took the form of a distinct academic discipline especially when people tried to understand the rise of Hitler. And it was not until late 1950's that Erik. H. Erikson gave the field its present name. In 1958, in his pioneering work on Martin Luther's life, "Young Man Luther", 
Erikson coined the term "identity crisis", a crisis that he believed Luther faced, which he believed he also saw in Gandhi.

Erikson's, "Gandhi's Truth: On the Origins of Militant Nonviolence" (1969), appears distinctly different. Understanding Gandhi is a challenge in itself, and that too through a Psychobiographical study is quite a feat in itself. Fundamentally, Erikson has applied Freud's psychoanalysis on Gandhi, but he has also developed his own eight stages of human life cycle development and tried to link it to the Hindu stages of life cycle. Basing his work on witnesses and recorders as well as Gandhi's autobiography, Erikson has attempted to review the history of Gandhi's truth.

As Richards (2005), another psychohistorian, puts it, one of the most significant insights Erikson makes in his masterful psychobiography is to study Gandhi through the eyes of the people who were encouraged by him to participate in his social movement. Erikson interviewed as witnesses the then young Indians who took part in the Ahmedabad mill workers strike. In 1918, influenced by Gandhi, whose appeal lay in his remarkable voice, an ethical voice, these men and women took part in the workers strike.

'Gandhi's Truth', describes a Westerner and a Psychoanalysts search for the historical presence of Mahatma Gandhi and for the meaning of what he called as Truth (Erikson, 1969). It is a psychological reconstruction of Gandhi's early years in Kathiawar, who as the youngest child of the family was a favourite of his mother. The narrative progresses to his years of exile in London, where he felt socially and psychologically isolated. His years in South Africa where he saw racial discrimination and insults of all kinds is also covered. There is a detailed analysis of the textile workers strike in Ahmedabad, 1918, where Gandhi put into practice his own variety of militant nonviolence or Satyagraha. Erikson describes the protest at Ahmedabad, where Gandhi concentrated on a strictly local labour dispute and in the course of resolving the dispute, had put his life at risk, by undertaking a fast. The method of fasting was new and unknown, except to a few friends of Gandhi who were already aware of Gandhi's protest techniques. The fact that Gandhi in his autobiography had underplayed the event had aroused Erikson's curiosity about 
Gandhi. Erikson's fascination with Gandhi was compounded by the fact that as a middle-aged man Gandhi returned to India from South Africa3.

Erikson endeavours to describe Gandhi's rise to leadership during his middle age on the occasion of the textile workers strike in 1918. He calls this incident as 'the Event' in Gandhi's life that provided the impetus to start his passive resistance in India.

In understanding the various concepts and methods associated with Gandhi, such as Fasting, Ahimsa and Satyagraha, these psychohistorians have analysed the incidents that left a deep impression on Gandhi, and it was the techniques that he learnt from these experiences that Gandhi later on used as his techniques.

Alluding to the interpretations blaming Gandhi's mother as the inspiration for the use of fasting as a protest technique, Erikson found no incident indicating that Putli Bai used fasting as punishment, except in so far as a deep-seated resentment over her manifold duties which may have induced her to insist on one sphere of privacy: that of worship and self-abnegation. And that her children had watched her anxiously (Erikson, 1969).

An almost similar analysis is seen in Richard's work when he says that Gandhi's maternal care prominently included nonviolence, (Ahimsa) not only as a religious requirement but also as a way of life. Putli Bai's vows of self-imposed suffering had taught Gandhi how to engage the concern and attention of others when a beloved person suffers ethically. Gandhi used this experience when he experimented with Satyagraha, hypothesizing that such experience might have relevance to a certain kind of ethical persuasion in politics (2005).

The transformation from Moniya to Mahatma had been the result of young Gandhi's ambivalence towards his father. Guilty of stealing gold to repay his brother's debt of rupees 25/- paid to eat meat, Gandhi had not confessed about this incident to his father. He had chosen not to confess not from fear of getting punished, but because of the fear of pain it would cause his father. Nevertheless, he mustered courage and confessed to his bed-ridden father. On reading the confession, his father did not rebuke him but had tears trickling down his cheeks, and at that moment Gandhi felt that his 
sin had been washed away. It was this incident that gave him a lesson in Ahimsa or non-violence (Wolpert, 2001).

Gandhi's defence of Satyagraha was that it was a means for Indians to find strength in them in a new way, without cowering before the mighty English. Satyagraha was not just about firmly breaking unjust laws but symbolised a tool to arouse the awareness of Indians to the injustice and oppose it unitedly and make the opponents feel guilty about their actions (Richards, 2005).

Another insightful incident is about Gandhi's childhood friend, Sheik Mehtab, who introduced him to meat eating, smoking and even a visit to a prostitute's house. Mehtab's role in Gandhi's life is seen as one of 'elemental significance' as he was not only such a "devil", but also as Gandhi held onto him to test the devil in himself. Mehtab became the personification of Gandhi's 'negative identity', that is, of everything in himself which he tried to isolate and subdue and which yet was part of him (Erikson, 1969).

To Wolpert the "curse" in Gandhi's life was the incident that Gandhi referred to his father as a short-tempered person and to a certain extent given to carnal pleasures, as his marriage to Putli Bai was the fourth one. Further, by insisting on early marriage for his son, he had cursed his son with his own carnal weakness. Wolpert, who refers to Erikson as following Kierkegaard's analysis of the lives of "spiritual innovators", calls this "the curse" of Gandhi's life. The "account" with his father could never be settled, leaving a lifelong "existential debt". That double shame as Gandhi called it4, linking his father's death to that of his first child, always remained in his mind the product of carnal lust, helping to explain his passionate preoccupation with Brahmacharya, upon which he focused intently during the last years of his life (Wolpert, 2001).

Whereas to Erikson, the "Curse" was related to the event that occurred on the night that Gandhi's father died. Gandhi who had been massaging his father's legs, left his uncle to take care of him, while he went to join his pregnant wife in bed, filled with carnal desire. Within a short time, he was informed that his father was no more. Gandhi by his own admission in his autobiography calls this as a shame, a double shame, as his firstborn also died a few days later. It is this event that Erikson calls "the curse" in Gandhi's life 
and that it must be heir to the Oedipus conflict. In Gandhi's case, the "feminine" service to his father would have served to deny the boyish wish to replace the father in possession of the mother and the youthful intention to outdo him as a leader in later life (1969). This is what set the pattern for the style of leadership that can defeat a superior adversary only non-violently. 5

On Gandhi's proclivity towards sexuality, Richards draws an analogy between Tolstoy and Gandhi, both of whose families had origins in political leadership; both had negative feelings about sexuality. Gandhi's feelings about marriage were filled with a sense of shame, and he shared with Tolstoy 6 the view that all non-procreational sex was evil, and ultimately that sex was evil; Consequently, in 1906 Gandhi took the vow of celibacy (Brahmacharya) after more than 20 years of marriage and four sons. Richards finds him, like Tolstoy, almost as bad a father as he was a husband (2005).

Reviewing Erikson's work Kearney opined that child marriage had left Gandhi with a horror of sexuality making it impossible for him to retreat to a monastic life to which his developing religiosity might have led. In Gandhi's case, the quest for sainthood, therefore, had to take a political form (Kearney,1970).

The role of the feminine characteristics or maternal side of Gandhi is seen as the focal point in identifying Gandhi's style of leadership. Patterns from history and culture have been woven well in narrating the stages in the life cycle of Gandhi. Erikson's choice of the 1918 Ahmedabad mill workers' strike, terming it the "Event" which initiated the first use of Satyagraha, is identified as the start of his $7^{\text {th }}$ stage of human life cycle of generativity in his middle age7.

On the controversy8 relating to Gandhi's testing his ability not to be sexually aroused despite having women near him at night, Erikson believes that it confounded the question whether the arrangement expressed a senile and eccentric self-testing, a belated need for younger women or a regression to an infantile need for motherly warmth. He believes that it could have been all of these (Erikson, 1969). 
Gandhi had told Manu that while he had been a father to many, he was a mother to her, indicating that he was there to cater to her need of a mother. Perhaps it was the other way round. Gandhi related in his autobiography that he was his mother's favourite child and that he was there whenever his mother needed him, just like he felt later about Manu needing him. Erikson pointedly observes that Gandhi felt that it was always his mother who needed him and never felt that he may have needed a mother. The maternalism governing their relationship was later acknowledged in the title of Manu's memoir: Bapu, My Mother (Erikson, 1969).

Gandhi is also seen as a revivalist as much as a political figure, in a sense that he wanted to instill values of social justice, self-reliance and public hygiene- that nurtured together would flower as a material and spiritual renewal on a national scale (Lelyveld, 2011).

Lelyveld viewed Gandhi's celibacy as a profound and deeply felt position. Going further, he believes that Gandhi's vow of Brahmacharya, a self-imposed celibacy, taken in 1906, was to become the foundation of his moral authority in the eyes of the Indian masses (Kunzru, 2011).

Gandhi was also only a human who was trying to deal with his demons in a way that others do but not all succeed. This is evidently seen when he took the Brahmacharya (celibacy) vow, which may have been his bisexual being coming to the fore. He had proclaimed earlier that there was the feminine in him and this evidenced in his maternal care even while handling the British Raj.

The theme of nursing a stricken superior adversary (for instance, nursing his father in younger days) reappeared in Gandhi's life when he enlisted for an ambulance corps in support of British war efforts when the Empire was in danger, although he was not in favour of British policy (Erikson,1969).

During the time of the last Satyagraha that Gandhi launched, he had misread the political situation and refused to accept partition as the basis of settlement. However, at the time of the actual transfer of power, when Gandhi was only a marginal figure, Congress accepted partition despite his objections. Gandhi was preoccupied with the communal violence that shook the country, and he blamed himself, saying that the earlier nonviolence of Indians had been the 
nonviolence of the weak, not the strong. Along these lines, George Orwell had cynically characterised Gandhi's nonviolence in India as successful because it suited the British interests. It was deemed successful because it allowed the British to continue and then end their rule on their own patronizing terms (Richards, 2005).

In all of these Gandhi narratives, they have explored the varied facets of his personality and leadership, attempting to retrieve his identity which is blurred between myth and history. In analysing Gandhi's truth, the psychohistorians have taken a clinical perspective, relying on concepts of developmental psychology, family system, and psychoanalysis to understand Gandhi. However, there are some shortcomings in these works, as most ignore all his other movements and only highlight the Ahmedabad mill workers strike of 1918. Erikson interpretations seem to have been based on his own experiences, and his eight stage life cycle seems a little farfetched. The psycho historians' unfamiliarity with Indian ethos may be one of the reasons for the shortcomings. Moreover, the analysis seems to be more of interpretations. Nevertheless, Erikson's pioneering work on psychohistory has inspired countless research studies. And as biographies are a historian's handmaid, psycho-biographies may also be viewed as such. Despite the shortcomings, psycho historical perceptions help to establish a broader context within which Gandhi's truth can be understood.

That Gandhi was only human with all human frailties is very clear from a psycho historical perception of the study of leadership. He grew from being a Moniya, who stole, ate meat, and even visited a prostitute house, to Mahatma. Too much is made of the honorific title Mahatma that Tagore bestowed on him.

Although Gandhi's rise to leadership is seen through the crucible of psychoanalysis, fortunately there is not too much psychology jargon. If the endeavour of Psychohistory is to enrich the understanding of the dynamics of the past and add new dimensions to the existing knowledge of historical processes, then the purpose has been served. 


\section{References}

Carlyle, T. (1899). Heroes and hero-worship. Philadelphia: Henry Altemus Company (p. 42). Retrieved from www. archives.org

De Graf, M. (2016, August 11). From Mahatma Gandhi to Abraham Lincoln: Great leaders who had mental illness - and triumphed as a result. The Daily Mail. Retrieved from http:/ / www.dailymail.co.uk.

Erikson, E. H. (1969).Gandhi's truth: On the origins of militant nonviolence (pp. 9, 51-52, 109, 128, 130, 135, 403-04).New York, NY:W.W. Norton \& Co. Retrieved from http://www. archives.org

Kunzru, H. (2011,March 29).Appreciating Gandhi through his human side. The New York Times. Retrieved from http:/ / www.nytimes.com.

Kearney, M. (1970). [Review of the book Gandhi's truth on the origins of militant non-violence by Erik H. Erikson]. American Anthropology, 72(5), 1197-98. Retrieved from http://onlinelibrary.wiley.com

Lal, V. (2000). Nakedness, nonviolence, and Brahmacharya: Gandhi's experiments in celibate sexuality. Journal of the History of Sexuality, 9(12), 105-136. Retrieved from https// scholar.google.com

Lelyveld, J. (2011). Great soul-Mahatma Gandhi and his struggle with India, p. 14.New York: Alfred and Knopf. Retrieved fromhttp:/ / library.aceondo.net/ebooks

Mazlish, B. (1971). Psychoanalysis and history (p. 14). New York: Grosset and Dunlap. Retrieved from www. archives.org

Piven, J. S., \& Lawton, H.W. (Eds). (2001). Psychological undercurrents of history (p.xi). Lincoln: iUniverse Inc.

Richards, D. A.J. (2005). Disarming manhood: Roots of ethical resistance (pp.92, 94, 108, 118). Ohio: Swallow Press. Retrieved from https// books.google.co.in

Spratt, P. (1939). Gandhism: An analysis. Madras: Huxley Press.

Wolpert, S. (2001).Gandhi's passion: The life and legacy of Mahatma Gandhi (pp. 16-17). New York, NY: Oxford University Press.

\section{Endnotes}

1Spratt's work was written at a time before Psychohistory as a discipline had emerged.

${ }^{2}$ What is Psychohistory. Retrieved from www.Psychohistory.us 
${ }^{3}$ Erikson had been looking for a historical figure to write about, and it was apt that "Young Man Luther" was followed by "Middle Aged Mahatma" (Erikson, 1969).

${ }^{4}$ Gandhi in his autobiography refers to the shame of his carnal desire even at the critical hour of his father's death especially when he had thought that his devotion to his parents was akin to his childhood ideal Shravana

5Gandhi's imperfections are understood better by a study of Gandhi through Psychohistory

6Tolstoy and Gandhi shared a psychology whose nonviolent roots were deeply influenced by a loving and maternalistic ethos

7Erikson's eight stages of human development : - 1st stage- Infant-18 months, Trust vs Mistrust; 2nd stage- 18 months- 3 years, Autonomy vs Shame \& Doubt; 3rd stage- 3-5 years, Initiative vs Guilt; 4th stage- 5-13 years, Industry vs Inferiority; 5 th stage- 13-21 years, Identity vs Role Confusion; 6th stage- 21-39 years, Intimacy vs Isolation; 7th stage-40-65 years, Generativity vs Stagnation; 8th stage- 65 and older, Ego Integrity vs Despair

${ }^{8}$ Vinay Lal refers to the fact that Gandhi was prepared to face public ignominy that knowledge of his sexual experiments was bound to produce 